\title{
Compatibility of Pretreated Coir Fibres (Cocos nucifera L.) with Portland Cement to Produce Mineral Composites
}

\author{
Joana M. Ferraz, ${ }^{1}$ Cláudio H. S. Del Menezzi, ${ }^{1}$ Mario R. Souza, ${ }^{2}$ \\ Esmeralda Y. A. Okino, ${ }^{2}$ and Sabrina A. Martins ${ }^{1}$ \\ ${ }^{1}$ Department of Forest Engineering, Faculty of Technology, University of Brasília, P.O. Box 04357, 70904-970 Brasília, DF, Brazil \\ ${ }^{2}$ Forest Products Laboratory, Brazilian Forest Service, Avenue L-4 Norte, SCEN Tr. 2, Lt. 4, Bloco B, 70818-900 Brasília, DF, Brazil
}

Correspondence should be addressed to Cláudio H. S. Del Menezzi, cmenezzi@unb.br

Received 17 May 2012; Revised 10 July 2012; Accepted 29 July 2012

Academic Editor: James Njuguna

Copyright (c) 2012 Joana M. Ferraz et al. This is an open access article distributed under the Creative Commons Attribution License, which permits unrestricted use, distribution, and reproduction in any medium, provided the original work is properly cited.

\begin{abstract}
The objectives of the present work were to evaluate the chemical compatibility between coir (Cocos nucifera L.) and cement and to study treatment methods to improve this compatibility. In the inhibition test, cement hydration temperature evolution was measured in the absence and presence of untreated and treated coir fibres (cold water, hot water and $\mathrm{NaOH}$ ), besides the addition of $4 \%$ of $\mathrm{CaCl}_{2}$. The chemical characterization of untreated and treated coir fibres was done by determining the content of extractives, lignin, and holocellulose. The inhibition test graded the untreated fibre as "extreme inhibition," ratifying the need to provide it a treatment. Treatments done on coir fibres affected positively the compatibility between cement and fibre, reducing the inhibition. The treatments reduced the lignin coir fibres' and extractives proportion, whose variation was significantly correlated with the reduction of the inhibitory index. These results indicate a possibility for future incorporation of these fibres into the production of mineral composites.
\end{abstract}

\section{Introduction}

In Brazil, the great consumption of coconut water, in natura or industrialized, has generated significant quantities of residues, mainly in the form of hulls [1]. Coir processing by agroindustries produces great quantities of fibres that can be used to manufacture strings, sacks, carpets, clothing, brushes, paint brushes, and, more recently, internal car coatings, as well as seats and shock absorbers [2]. Although this fibre has been employed within a broad range of products, given the great products' volume, it is very important to study new forms of utilization, such as the production of composite materials.

Nowadays, cement-wood composites present major importance on civil construction market due to its low-cost and easy production, as its composition uses the abundant residues from timber and agroindustries, thus being a viable alternative for these residues. Besides, these composites have found great worldwide acceptance, as this mixture combines desirable properties of lignocellulosic material and cement
[3]. These composites can be used as linings, floors, screens, external coatings, specialized coatings for acoustical isolation, protection elements against fire, and so forth [4].

The lignocellulosic part of these composites is obtained from fast-growing or low-value wood species, agriculture residues, and so forth [5]. The addition of fibres to cement brings some advantages to the composites, such as high resistance to tension, relatively high modulus of elasticity, good resistance to fire, and resistance against fungi and termites, besides its technology of easy development $[5,6]$. However, it presents some drawbacks: high variation in compatibility between lignocellulosic materials and cement due to inhibiting substances (sugars, extractives, hemicelluloses, etc.) and the relative chemical efficiency of the additives required to surpass the lignocellulosic inhibiting effect on the cement setting $[7,8]$.

In spite of these restrictions, there are several strategies to improve the lignocellulosic material compatibility with cement and other agglutinating minerals, increasing, consequently, these composites' resistance [9]. Several researches 
TABLE 1: Raw material grading according to inhibition index.

\begin{tabular}{lc}
\hline Inhibition index $(I)$ & Grading \\
\hline$I \leq 10$ & Low inhibition \\
$10<I \leq 50$ & Medium inhibition \\
$50<I \leq 100$ & High inhibition \\
$I>100$ & Extreme inhibition \\
\hline
\end{tabular}

Source: Okino et al. [13].

have shown that adequate treatments are able to minimize the effects of those inhibiting substances. The treatments include basically the removal of the inhibiting substances through the immersion of the lignocellulosic material in water at room temperature [10] or in hot water $[8,11]$, immersion of the material in $\mathrm{NaOH}$ aqueous solution [12], addition of accelerating chemical substances of the cement setting such as calcium chloride $\left(\mathrm{CaCl}_{2}\right)[13,14]$, magnesium chloride $\left(\mathrm{MgCl}_{2}\right)$ [7, 15], and substitution of part of the cement by active silica [16]. In this context, this study presented the following objectives: to evaluate, by means of thermometric test, the chemical compatibility between cement and coir fibre (Cocos nucifera L.) and to study methods to improve this compatibility.

\section{Material and Methods}

2.1. Inhibition Test. A bale of green coir fibre (Cocos nucifera L.) was purchased from the enterprise Coco Comandatuba Ltda., located in Ilhéus, BA, Brazil. The fruits were harvested from 10-year-old coir palms between the seventh and ninth month after the inflorescence. Afterwards, the fibres were processed in a hammer mill with $6 \mathrm{~mm}$ mesh openings. The processed fibres were then manually selected, removing odd material and reducing them into smaller dimensions in a Wiley macromill. The obtained particles were graded through a Produtest vibrator to obtain the fraction that passed through a 40 mesh $(0.42 \mathrm{~mm})$ and collected at a 60 mesh $(0.25 \mathrm{~mm})$ screen $(-40,+60)$.

The method applied to evaluate compatibility between coir fibre and cement was based on Weatherwax and Tarkow [17] and Hofstrand et al. [18] previous studies. In the present test, the cement hydration temperature evolution was measured in the absence and presence of coir fibre (Cocos nucifera L.) to determine the inhibition index of the cement setting by the fibre. The tests were performed with four repetitions each, in an air-conditioned room at controlled temperature of $20 \pm 3^{\circ} \mathrm{C}$ and controlled relative humidity of $60 \pm 5 \%$. For the inhibition test, three previous treatments were applied on the coir fibre: immersion into water at room temperature during 72 hours, immersion into hot water at $80^{\circ} \mathrm{C}$ during 90 minutes, and immersion into a 5\% $\mathrm{NaOH}$ aqueous solution p.v. during 72 hours. After these treatments, the fibres were air dried and those submitted to alkali treatment were previously triple washed to remove excess of $\mathrm{NaOH}$. In order to evaluate the effect of a common additive, calcium chloride $\left(\mathrm{CaCl}_{2}\right)$ was mixed with untreated fibre and the inhibition test was also carried out.
The hydration test was conducted using $200 \mathrm{~g}$ of Portland cement CPII Z-32, $15 \mathrm{~g}$ of coir fibre, and $90.5 \mathrm{~mL}$ of distilled water, which were all mixed up and put into plastic bags. Each plastic bag was placed into a thermal recipient and then a "K-" type thermocouple cable was placed into the midst of the mixture. The thermocouple cable was connected to a signal receiver, and data was read and converted into temperature values through the Lynx computer software. Temperature readings were made at 10 -second intervals during 22 hours, totaling nearly 7,900 readings. The inhibition index $(I)$ in percentage was calculated according to (1) [18]. The compatibility between coir fibre and cement was classified according to Table 1

$$
\begin{aligned}
I= & {\left[\left(\frac{T_{\mathrm{cem}}-T_{m}}{T_{\mathrm{cem}}}\right) \times\left(\frac{H_{m}-H_{\mathrm{cem}}}{H_{\mathrm{cem}}}\right) \times\left(\frac{S_{\mathrm{cem}}-S_{m}}{S_{\mathrm{cem}}}\right)\right] } \\
& \times 100
\end{aligned}
$$

where $T_{\text {cem }}$ is the maximum temperature of cement/water mixture $\left({ }^{\circ} \mathrm{C}\right) ; T_{m}$ is the maximum temperature of coir/cement/water mixture $\left({ }^{\circ} \mathrm{C}\right) ; H_{\text {cem }}$ is the time (h) to reach maximum hydration temperature of cement and cement/water mixture; $H_{m}$ is the Time (h) to reach maximum hydration temperature of cement mixture in the coir/cement/water mixture; $S_{\text {cem }}$ is the maximum temperature increment of the curve in the cement/water mixture $\left({ }^{\circ} \mathrm{C} / \mathrm{h}\right) ; S_{m}$ is the maximum temperature increment of the curve in the coir/cement/water mixture $\left({ }^{\circ} \mathrm{C} / \mathrm{h}\right)$.

\subsection{Chemical Characterization of Treated and Untreated} Coir Fibres. The chemical characterization of untreated and treated coir fibres-cold water (immersion in water at room temperature for 72 hours), hot water (immersion in water at $80^{\circ} \mathrm{C}$ for 90 minutes), and $\mathrm{NaOH}$ (immersion in $5 \% \mathrm{NaOH}$ aqueous solution p.v. for 72 hours) - was done by means of determining extractives, lignin, and holocellulose contents.

2.2.1. Determination of Extractives. The content of extractives was determined according to TAPPI T 204 standard [19]. For this determination, the coir fibre was ground and graded through a system of vibration screens, as previously described. Initially, $3 \mathrm{~g}$ of coir fibre sample were weighedin duplicate-in a cellulose tube. Both cellulose tubes were placed into a Soxhlet extractor, and extraction was done for eight hours after the first reflux. Afterwards, the extraction through ethanol was effected for a period of six hours after the first reflux, leaving the samples to dry at each extraction. The sample was then dried in heater to eliminate the excess of solvents, and weighed. Thus, the percentage of total extractives $\left(E_{\mathrm{TOTAL}}\right)$ was calculated according to the following:

$$
E_{\mathrm{TOTAL}}(\%)=\left(\frac{P_{a}}{P_{s}}\right) \times 100,
$$

where $P_{a}$ is the extractive dry weight, $g$; $P_{s}$ is the sample dry weight, $g$. 




Figure 1: Hydration curve of the mixture between untreated/ treated coir fibre and cement.

2.2.2. Determination of Soluble/Insoluble Lignin and Holocellulose Contents. Soluble and insoluble lignin contents in acid were determined according to the norms of analysis proceedings in laboratories LAP 003 [20] and LAP 004 [21], respectively. The extractive-free samples were submitted to acid hydrolysis to determine lignin contents.

Insoluble Lignin. $0.3 \mathrm{~g}$ from the extractive-free sample were placed into the test tube and submitted to hydrolysis with sulphuric acid at $72 \%$, placed into a double boiler at temperature of $30 \pm 1^{\circ} \mathrm{C}$ for 2 hours, under agitation at 15-minute intervals. Once this period elapsed, the material was transferred to penicillin flasks using $84 \mathrm{~mL}$ of water, and flasks were sealed and taken to an autoclave for one hour at $120 \pm 1{ }^{\circ} \mathrm{C}$. After this process, flasks were left to rest at atmosphere temperature for 30 minutes and, afterwards, filtered using prior weighed Gooch crucibles; the residues were washed with water and dried in a heater at $105 \pm$ $2^{\circ} \mathrm{C}$ for four hours and then weighed. The insoluble lignin content $\left(L_{i}\right)$ given in percentage was determined through the following:

$$
L_{i}(\%)=\left(\frac{m_{1}}{m_{2}}\right) \times 100,
$$

where: $m_{1}$ is the dry-base residue mass, g; and $m_{2}$ is the drybase sample mass, $\mathrm{g}$.

Soluble Lignin. An aliquot of the filtered material was analysed in a Femto 700 plus spectrophotometer, in which absorbance was measured in a $205 \mathrm{~nm}$ length wave, having sulphuric acid at $4 \%$ as blank. The soluble lignin concentration $\left(L_{\mathrm{s}}\right)$ was calculated, as shown by the following.

$$
L_{s}(\%)=\left(\frac{L_{\mathrm{SOL}} \times V \times L / 1000 \mathrm{~mL}}{W \times T_{\mathrm{FINAL}} / 100}\right) \times 100,
$$

where $L_{\mathrm{SOL}}$ is the soluble lignin $(\mathrm{g} / \mathrm{L}) ; V$ is the volume of filtered material $(87 \mathrm{~mL}) ; W$ is the initial mass $(\mathrm{g}) ; T_{\mathrm{FINAL}}$ is the content of sample solids (\%).
TABLe 2: Inhibitory index of coir fibre mixed with Portland cement.

\begin{tabular}{lcccc}
\hline Treatment & $H_{m}(\mathrm{~h})$ & $T_{m}\left({ }^{\circ} \mathrm{C}\right)$ & $S_{m}\left({ }^{\circ} \mathrm{C} / \mathrm{h}\right)$ & $I(\%)$ \\
\hline Cement & 11.00 & 55.06 & - & - \\
Untreated & 1.08 & 30.47 & 28.21 & $186.28^{\mathrm{A}}$ \\
Cold water & 20.02 & 32.92 & 1.64 & $20.85^{\mathrm{B}}$ \\
$80^{\circ} \mathrm{C}$ water & 17.56 & 34.15 & 1.94 & $14.07^{\mathrm{B}}$ \\
$\mathrm{CaCl}_{2}$ & 14.86 & 42.88 & 2.89 & $2.97^{\mathrm{C}}$ \\
$\mathrm{NaOH}$ & 12.87 & 46.96 & 3.65 & $2.24^{\mathrm{C}}$ \\
\hline
\end{tabular}

Note: distinct letters in the same column indicate a significant difference by the LSD test at $\alpha=0.05$ level; $H_{m}$ : time to reach maximum temperature; $T_{m}$ : maximum temperature; $S_{m}$ : maximum increment of temperature.

Soluble lignin $\left(L_{\mathrm{SOL}}, \mathrm{g} / \mathrm{L}\right)$ was determined as shown by the following:

$$
L_{\mathrm{SOL}}(\mathrm{g} / \mathrm{L})=\left(\frac{A}{b \times a}\right) \times \mathrm{df},
$$

where $A$ is the absorbance at $205 \mathrm{~nm}$; $\mathrm{df}$ is the dilution factor; $b$ is the cuvette path length, $10 \mathrm{~mm}$; $a$ is the absorptivity equal to $110 \mathrm{~cm}^{-1} \mathrm{~g}^{-1} \mathrm{~L}$.

The total lignin content $\left(L_{\text {TOTAL }}\right)$, given in percentage, consisted of the fraction sum of soluble lignin $\left(L_{s}, \%\right)$ and insoluble lignin $\left(L_{i}, \%\right)$.

Holocellulose. The percentage of holocellulose (Hol, \%) was calculated according to (6) given by Andrade et al. [22]:

$$
\operatorname{Hol}(\%)=100-\left(E_{\mathrm{TOTAL}}-L_{\mathrm{TOTAL}}\right) .
$$

2.3. Statistical Analysis. Compatibility of coir fibre with cement and the analysis of the chemical composition of green coir (contents of lignin and extractives) were analysed through the analysis of variance (ANOVA). When there was rejection of the hypothesis of nullity, the least-significantdifference (LSD) median test was applied at the 95\% probability level.

\section{Results and Discussion}

The values obtained from the inhibition test are presented in Table 2. The mixture of the ideal material should attain maximum temperature $\left(T_{m}\right)$ in the shortest time $\left(H_{m}\right)$ with maximum increment $\left(S_{m}\right)$. The inhibition index $(I)$ of the untreated coir-cement mixture was $186.28 \%$, considered "extreme inhibition" according to Table 1. A similar observation was made by Olorunnisola [4] when studying coir fibre for the confection of mineral panels.

The inhibition indexes of treatments with cold and hot water were $20.85 \%$ and $14.07 \%$, respectively, being graded as "medium inhibition" according to Table 1, without significant statistical difference between these treatments. The treatments with $\mathrm{NaOH}$ and addition of $\mathrm{CaCl}_{2}$ presented lower values of inhibition indexes, $2.24 \%$ and $2.97 \%$, respectively, thus changing these fibres compatibility with cement, which were graded, according to Table 1, as "low inhibition." Thus, the efficiency of the chemical treatments on coir fibres 
at inhibition reduction of the Portland cement setting was evinced.

Asasutjarit et al. [8], studying the properties of panels strengthened with treated coir fibres, observed that the treatments (immersion in cold and hot water) increased the efficiency of coir fibres as a compound strengthening, increasing the interfacial adherence between the coir and the matrix. The hydration curves in the course of time of standard Portland cement mortar and its mixtures with untreated and treated coir fibres (cold water, hot water, and $\mathrm{NaOH}$ ) are presented in Figure 1. These profiles qualitatively evaluate the behaviour of cement setting with the addition of treated and untreated coir fibres.

The inhibitory effect of this fibre was evident in relation to the reactions of cement hydration, once the standard mortar reached the peak temperature of $55.1^{\circ} \mathrm{C}$ in 11 hours, and the untreated fibre reached a maximum temperature of $30.5^{\circ} \mathrm{C}$ in about one hour, as presented in Table 2. Assuredly, there is a great difference and it confirms that untreated coir fibres cause extreme inhibition on the cement setting. According to Zhou and Kamdem [23], the $T_{m}$ reduction may be caused by a reduced value of cement hardening or by the presence of a determined mass of lignocellulosic material which did not contribute to generate heat but, on the contrary, absorbed it. It could also be observed that hotwater treatment considerably decreased the inhibitory index, but the maximum temperature was relatively low $\left(32.9^{\circ} \mathrm{C}\right)$. The cold-water treatment yielded slightly higher temperature $\left(34.1^{\circ} \mathrm{C}\right)$, but the curve (behind the hot-water curve) was almost the same of that observed for hot-water treatment.

Table 3 shows the contents of lignin, extractives, and holocellulose for coir fibre under different treatments. It was verified that the analysis of the untreated fibre chemical composition confirmed the presence of high lignin content, thus corroborating the results found by other authors $[1,8,24]$. It can be observed that the chemical composition presented variation between treatments. The untreated and treated coir fibres in cold and hot water presented, respectively, $34.24 \%$, $30.80 \%$, and $29.73 \%$ of lignin contents. However, there was no statistically significant difference between untreated and cold-water treatment, nor between the other treatments in cold water, hot water, and $\mathrm{NaOH}$.

Asasutjarit et al. [8] studied the production of reinforced panels with coir fibre and Abdul Khalil et al. [24] determined its chemical composition. The lignin contents of the untreated fibre were $32.1 \%$ and $32.8 \%$, respectively, and these values were lower than those found in the present research. Corradini et al. [1], studying the chemical composition of several coir varieties, observed that lignin varied from $37.2 \%$ to $43.9 \%$, depending on the culture, which was higher than those presented in this study. It was verified that, in relation to extractives, the untreated and the coldwater-treated fibre presented similar extractives contents $(4.86 \%$ and $4.82 \%$, resp.) without statistically significant difference between them; on the other hand, hot-water and $\mathrm{NaOH}$ treatments presented statistically different extractives contents (3.68\% and $2.48 \%$, resp.).

Figure 2 shows the relationship between the coir fibre chemical composition and the inhibitory index. It can be

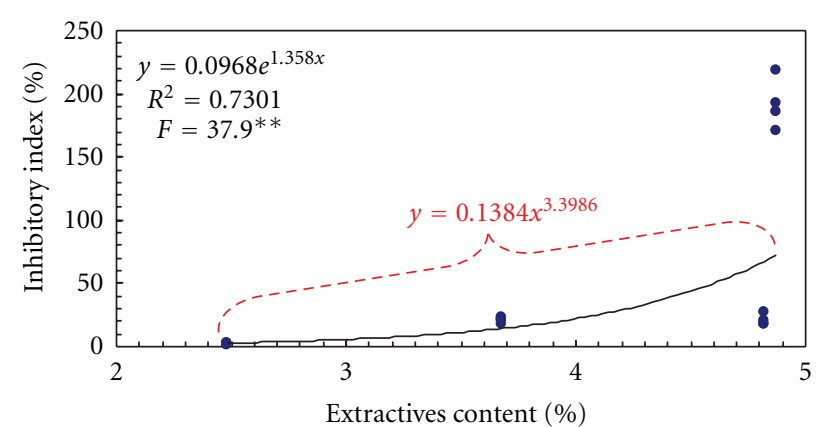

(a)

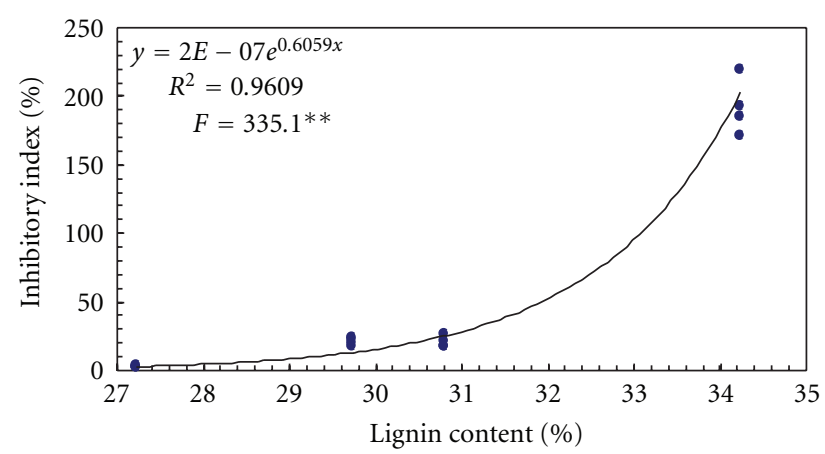

(b)

FIGURE 2: Relationship between extractive/lignin content and inhibitory index of coir fibres on cement setting. Note: ${ }^{* *}$ statistically significant at $\alpha=0.01$ level.

observed that the higher the extractive and lignin content, the greater the inhibitory effect on cement setting. The exponential models fitted to explain this relationship were highly statistically significant $(P<0.0001)$. Nevertheless, the scattering data of the inhibitory index of untreated fibres observed at extractive content nearly $4.86 \%$ is relatively high. Therefore, when these data were not included in the analysis, a highly significant power model $\left(y=0.1384 x^{3.3986} ; F=\right.$ $\left.61.2^{* *}\right)$ was fitted and the coefficient of determination $\left(R^{2}\right)$ was considerably higher: 0.8125 .

On the other hand, the lignin content variation of the coir fibre almost fully explains (96.1\%) the inhibitory index variation. In this context, it is clear that the treatments performed on the coir fibres significantly altered their chemical composition, which led to a drastic reduction of the inhibitory effect on cement setting. According to Hachmi and Moslemi [25] and Sutigno [10], this phenomenon occurs because, generally, there is an inverse relation between content of wood extractives and hydration temperature of the cement-wood mixture. Sutigno [10] corroborated that after the immersion of Tectona grandis wood in cold and hot water, the wood tannin contents and sugars were reduced, so the hydration temperature was increased. Miller and Moslemi [26] stated that complex chemical and physical processes occur during cement hydration, so the cause of the inhibitory effect of the lignocellulosic material is difficult to be evinced. Nevertheless, the authors brought some explanations about it and they discussed that lignocellulosic 


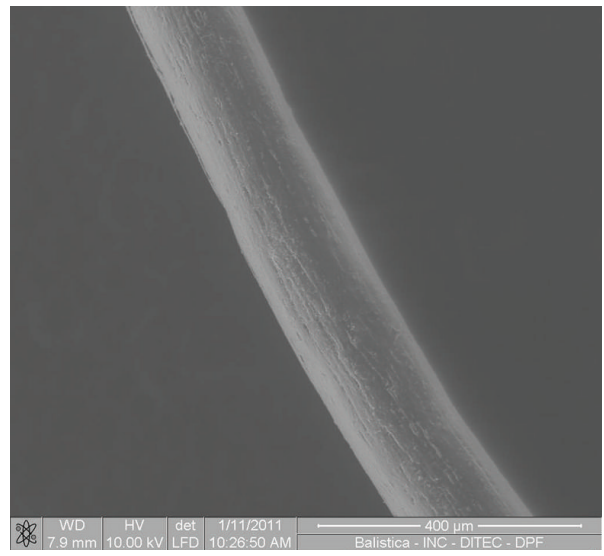

(a)

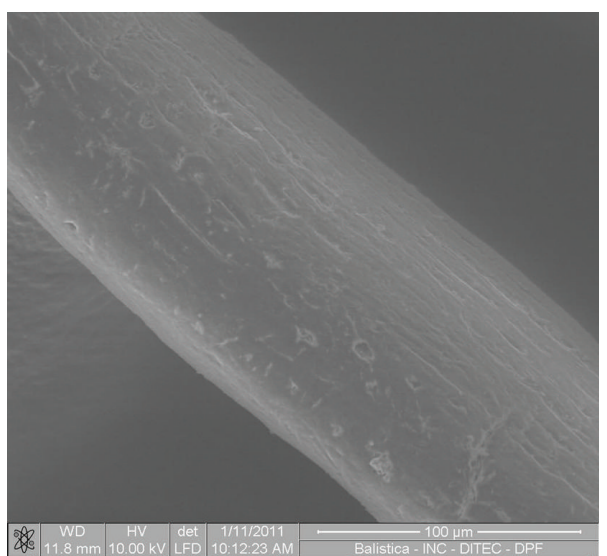

(c)

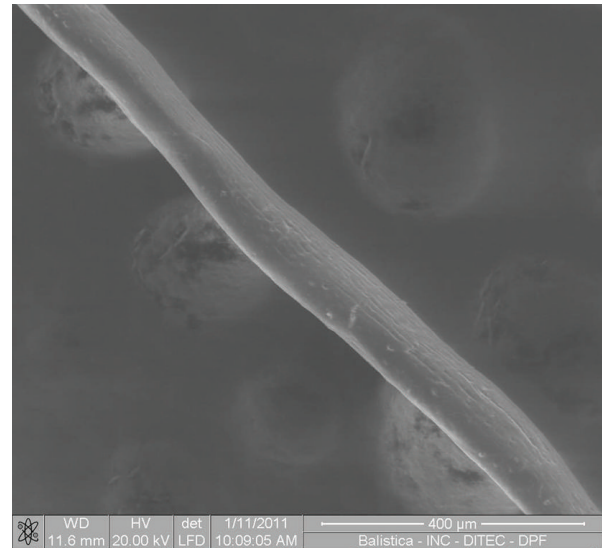

(b)

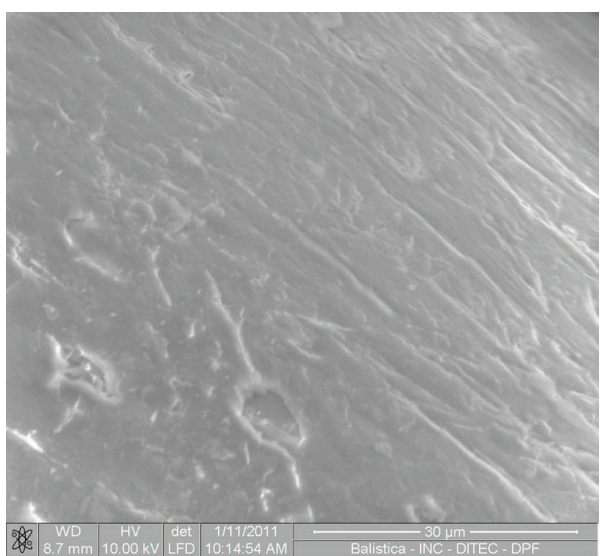

(d)

FIGURE 3: SEM photomicrographs $(400 \mu \mathrm{m})$ of untreated (a) and $\mathrm{NaOH}$-treated $(400,100$, and $30 \mu \mathrm{m})$ coir fibre surfaces (b-d).

TABLE 3: Chemical composition of the coir fibre according to pretreatment used.

\begin{tabular}{lccc}
\hline Treatment & Lignin total (\%) & Extractives (\%) & Holocellulose (\%) \\
\hline Untreated & $34.24^{\mathrm{A}}$ & $4.86^{\mathrm{A}}$ & 60.90 \\
Cold water & $30.80^{\mathrm{AB}}$ & $4.82^{\mathrm{A}}$ & 64.38 \\
Hot water & $29.73^{\mathrm{B}}$ & $3.68^{\mathrm{B}}$ & 66.59 \\
$\mathrm{NaOH}$ & $27.23^{\mathrm{B}}$ & $2.48^{\mathrm{C}}$ & 70.29 \\
\hline
\end{tabular}

Note: distinct letters in the same column indicate a significant difference by the LSD test at $\alpha=0.05$ level.

polymers can affect considerably the crystallization reactions of the cement. According to the authors, the following mechanisms might be involved in this phenomenon: sugar migration to the wood surface, and solubilization and/or degradation of wood polymers caused by calcium hydroxide formed during cement hydration.

Figure 3 depicts the surface of untreated (a) and $\mathrm{NaOH}-$ treated coir fibres (b-d) according to the scanning electronic microscope (SEM) evaluation. The comparison between the material at the same magnification $(\mathrm{a}, \mathrm{b})$ reveals that the untreated fibre surface (a) is not clean probably because of the presence of fat, wax, and other compounds. On the other hand, the $\mathrm{NaOH}$-treated fibre surface (b) is cleaner and some erosion can be seen, evincing the removal or degradation of the components (wax, fat, and extractives) that play important role on the inhibition of cement setting. As the magnification is improved $(\mathrm{c}, \mathrm{d})$, the erosion on the surface becomes more evident. Indeed, several authors have observed a higher degree of roughness of alkali-treated coir fibres [27-29]. Rout et al. [27], studying the surface morphology of alkali-treated ( $5 \%$ solution) coir fibre, found that a large amount of pith was revealed probably due to the removal of tyloses and globular fatty deposits.

Calado et al. [28] evinced the lignin removal from the coir fibre surface soaked in $2 \% \mathrm{Na}_{2} \mathrm{SO}_{3}$ solution. The SEM micrographs clearly showed that chemical treatment imparted significant modification of the coir fibre outer layer, which, according to the authors, is rich in lignin. The removal of tyloses was also mentioned by Rout et al. [29] as consequence of alkali treatment of coir fibres. Recently, Ramadevi et al. [30] found that alkali treatment removed the waxy epidermal tissue, and most of the lignin and hemicelluloses components of abaca fibres (Musa textilis).

It was observed that the holocellulose values (cellulose + hemicellulose) in the different treatments went up with the reduction of the other chemical constituents, such as lignin and extractives. The untreated fibre presented lower holocellulose content $(60.90 \%)$, while the $\mathrm{NaOH}$ 
treatment obtained the highest holocellulose value (70.29\%). The holocellulose content of the untreated coir fibre is higher than the value observed by Abdul Khalil et al. [24], which was $56.3 \%$, and lower than that observed by Asasutjarit et al. [8], 68.9\%. The content of holocellulose found in the hot-water treatment may be partially compared to the results presented by Asasutjarit et al. [8], which was 73.9\%, value superior to that verified in the present study. The holocellulose content rise with the decrease of extractives and lignin contents was also observed by Asasutjarit et al. [8]; however, holocellulose did not increase in absolute terms, only in relative terms.

\section{Conclusions}

(i) The untreated coir fibre is extremely inhibiting to the cement setting, thus confirming the necessity for pretreatment.

(ii) The studied treatments reduced the contents of extractives and lignin, minimizing the inhibiting effect of coir fibres to the Portland cement setting, thus enabling the incorporation of these fibres into the production of reinforced mineral panels.

(iii) The treatment with $\mathrm{NaOH}$ and the addition of $\mathrm{CaCl}_{2}$ considerably altered the compatibility of the coir fibre, which was graded as low inhibition.

\section{References}

[1] E. Corradini, M. F. Rosa, B. P. Macedo, P. D. Paladin, and L. H. C. Mattoso, "Composição química, propriedades mecânicas e térmicas da fibra de frutos de cultivares de coco verde," Revista Brasileira de Fruticultura, vol. 31, no. 3, pp. 837-846, 2009.

[2] F. G. V. Faguri, Avaliação de fibras naturais para a fabricação de compósitos: açaí, coco e juta [M.S. thesis], Centro Tecnológico, Universidade Federal do Pará, Belém, Brazil, 2005.

[3] G. R. Coates, "Product application of wood-cement particleboards including applied finishes," in Proceedings of the International Inorganic-bonded Wood and Fiber Composite Materials Conference, pp. 189-192, Washington, DC, USA, 1994.

[4] A. O. Olorunnisola, "Effects of pre-treatment of rattan ( $\mathrm{Lac}$ cosperma secundiflorum) on the hydration of Portland cement and the development of a new compatibility index," Cement and Concrete Composites, vol. 30, no. 1, pp. 37-43, 2008.

[5] K. E. Semple, R. B. Cunningham, and P. D. Evans, "The suitability of five Western Australian mallee eucalypt species for wood-cement composites," Industrial Crops and Products, vol. 16, no. 2, pp. 89-100, 2002.

[6] W. Wang and G. Huang, "Characterisation and utilization of natural coconut fibres composites," Materials and Design, vol. 30, no. 7, pp. 2741-2744, 2009.

[7] Y. M. Wei, Y. G. Zhou, and B. Tomita, "Study of hydration behavior of wood cement-based composite II: effect of chemical additives on the hydration characteristics and strengths of wood-cement composites," Journal of Wood Science, vol. 46, no. 6, pp. 444-451, 2000.

[8] C. Asasutjarit, J. Hirunlabh, J. Khedari, S. Charoenvai, B. Zeghmati, and U. C. Shin, "Development of coconut coirbased lightweight cement board," Construction and Building Materials, vol. 21, no. 2, pp. 277-288, 2007.
[9] K. E. Semple and P. D. Evans, "The manufacture of cementbonded paricleboard (CBPs) from Field-chipped mallee eucalypt residues. Wood-cement composites: suitability of western Australian mallee eucalypt, blue gum and melaleuca," pp. 1724, 2004.

[10] P. Sutigno, "Effect of aqueous extraction of wood-wool on the properties of wood-wool cement board manufactured from teak (Tectona grandis)," in Proceedings of the Wood-Cement Composites in the Asia-Pacific Region Proceedings, pp. 24-28, Canberra, Australia, 2000.

[11] J. M. Ferraz, C. H. S. Del Menezzi, D. E. Teixeira, and S. A. Martins, "Effects of treatment of coir fiber and cement/fiber ratio on properties of cement bonded composites," BioResources, vol. 6, no. 3, pp. 3481-3492, 2011.

[12] S. V. Prasad, C. Pavithran, and P. K. Rohatgi, "Alkali treatment of coir fibres for coir-polyester composites," Journal of Materials Science, vol. 18, no. 5, pp. 1443-1454, 1983.

[13] E. Y. A. Okino, M. R. S. Souza, M. A. E. Santana, M. E. Sousa, and D. E. Teixeira, "Chapa aglomerada de cimento-madeira de Hevea brasiliensis Müll,” Revista Árvore, vol. 28, no. 3, pp. 451-457, 2004.

[14] A. O. Olorunnisola, "Effects of husk particle size and calcium chloride on strength and sorption properties of coconut huskcement composites," Industrial Crops and Products, vol. 29, no. 2-3, pp. 495-501, 2009.

[15] J. V. F. Latorraca and S. Iwakiri, "Efeitos do tratamento das partículas de Eucalyptus dunnii (Maid), da variação da relação madeira-cimento e do uso de aditivos sobre as propriedades físicas e mecânicas de chapas de madeira-cimento," Cerne, vol. 6, no. 1, pp. 68-76, 2000.

[16] C. H. S. D. Menezzi, V. G. De Castro, and M. R. De Souza, "Production and properties of a medium density woodcement boards produced with oriented strands and silica fume," Maderas: Ciencia y Tecnologia, vol. 9, no. 2, pp. 105$115,2007$.

[17] R. C. Weatherwax and H. Tarkow, "Effect of wood on setting of Portland cement," Forest Products Journal, vol. 14, pp. 567$570,1964$.

[18] A. D. Hofstrand, A. A. Moslemi, and J. F. Garcia, "Curing characteristics of wood particles from nine northern Rocky Mountain species mixed with Portland cement," Forest Products Journal, vol. 34, no. 2, pp. 57-61, 1984.

[19] Technical Association of the Pulp and Paper Industry, Solvent Extractives of Wood and Pulp. TAPPI Test Methods T 204, Tappi Technology Park, Atlanta, Ga, USA, 1997.

[20] D. Templeton and T. Ehrman, "Determination of acidinsoluble lignin in biomass," ASTM-Chemical Analysis and Testing Task Laboratory Analytical Procedure Methods, LAP003, p. 14, 1995.

[21] T. Ehrman, "Determination of acid-soluble lignin in biomass," ASTM-Methods Chemical Analysis and Testing Task Laboratory Analytical Procedure, LAP-004, p. 7, 1996.

[22] M. C. N. Andrade, M. T. A. Minhoni, C. A. Sansígolo, and D. C. Zied, "Análise química da madeira e casca de diferentes tipos de eucalipto antes e durante o cultivo de shiitake em toras," Revista Árvore, vol. 34, no. 1, pp. 165-175, 2010.

[23] Y. Zhou and D. Pascal Kamdem, "Effect of cement/wood ratio on the properties of cement-bonded particleboard using CCAtreated wood removed from service," Forest Products Journal, vol. 52, no. 3, pp. 77-81, 2002.

[24] H. P. S. Abdul Khalil, M. Siti Alwani, and A. K. Mohd Omar, "Chemical composition, anatomy, lignin distribution, and cell wall structure of malasian plant waste fiber," BioResources, vol. 1, no. 2, pp. 220-232, 2006. 
[25] M. H. Hachmi and A. A. Moslemi, "Correlation between wood-cement compatibility and wood extractives," Forest Products Journal, vol. 39, no. 6, pp. 55-58, 1989.

[26] D. P. Miller and A. A. Moslemi, "Wood-cement composites: effect of model compounds on hydration characteristics and tensile strength," Wood and Fiber Science, vol. 23, no. 4, pp. 472-482, 1991.

[27] J. Rout, S. S. Tripathy, S. K. Nayak, M. Misra, and A. K. Mohanty, "Scanning electron microscopy study of chemically modified coir fibers," Journal of Applied Polymer Science, vol. 79, no. 7, pp. 1169-1177, 2001.

[28] V. Calado, D. W. Barreto, and J. R. M. D’Almeida, “The effect of a chemical treatment on the structure and morphology of coir fibers," Journal of Materials Science Letters, vol. 19, no. 23, pp. 2151-2153, 2000.

[29] J. Rout, M. Misra, A. K. Mohanty, S. K. Nayak, and S. S. Tripathy, "SEM observations of the fractured surfaces of coir composites," Journal of Reinforced Plastics and Composites, vol. 22, no. 12, pp. 1083-1100, 2003.

[30] P. Ramadevi, D. Sampathkumar, C. V. Srinivasa, and B Bennehalli, "Effect of alkali treatment on water absorption of single cellulosic abacá fiber," BioResources, vol. 7, no. 3, pp. 3515-3524, 2012. 

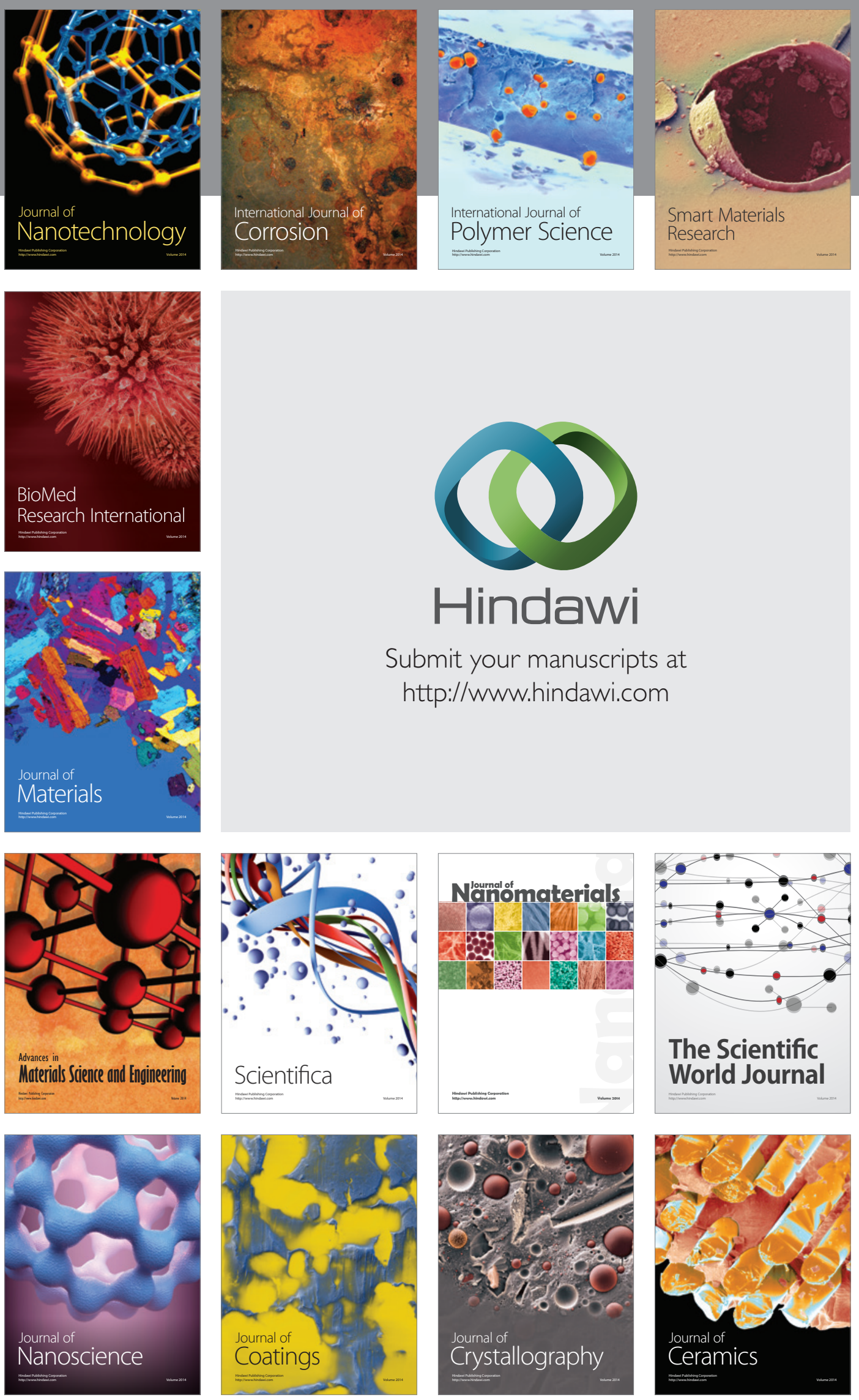

The Scientific World Journal

Submit your manuscripts at

http://www.hindawi.com

\section{World Journal}

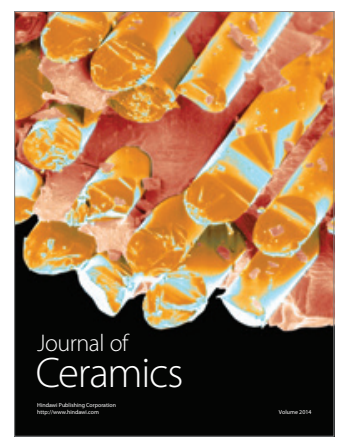

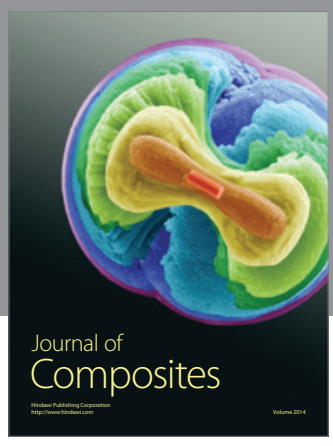
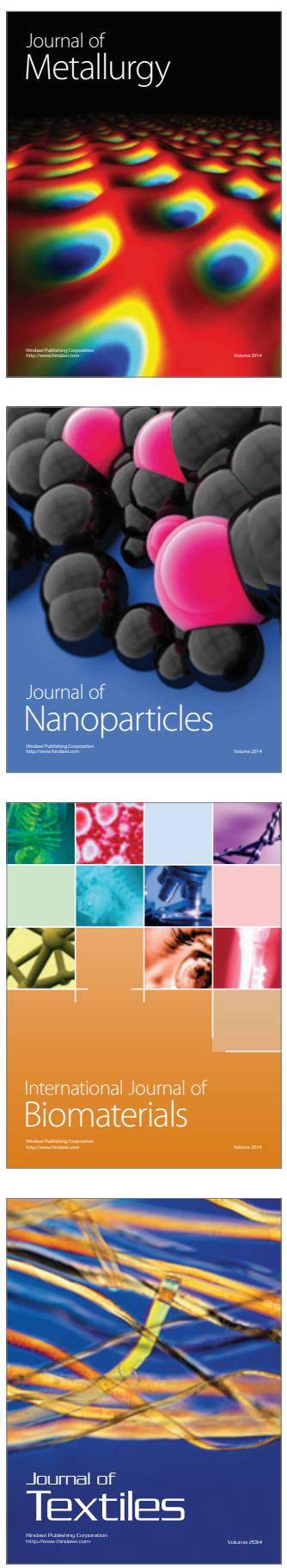